\title{
Evaluative Frameworks and Models for Health Information Systems (HIS) and Health Information Technologies (HIT)
}

\author{
Amanda L. JOSEPH ${ }^{\mathrm{a}, 1}$, Eleah STRINGER ${ }^{\mathrm{a}}$, Elizabeth M. BORYCKI ${ }^{\mathrm{a}, \mathrm{b}}$ \\ and Andre W. KUSHNIRUK ${ }^{\mathrm{a}}$

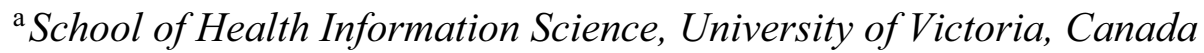 \\ ${ }^{\mathrm{b}}$ Michael Smith Foundation for Health Research, Canada
}

\begin{abstract}
Evaluation criteria for health information systems (HIS) and health information technologies (HIT) is broad, diverse and lacks a gold standard approach that could be leveraged, to evaluate clinical systems at various stages of their system development life cycle (SDLC). Without generalizable tools such as frameworks or models, comparative analysis across HIS and HIT is not possible. This paper presents the findings from a scoping review, utilizing the Arksey and O'Malley methodology [1]. The objective of this review is two-fold: 1) to classify models and frameworks published between the years 2010-2020 according to their level of evaluative focus (e.g. micro, meso, macro, multi), 2) to identify the countries where these models and frameworks have been employed for the purpose of evaluation, using the International Medical Informatics Association (IMIA) Represented Regions [3]. The results demonstrated the heterogeneity of evaluation models and frameworks currently used in health informatics and reflected the necessity for more adaptive approaches to HIS and HIT evaluation.
\end{abstract}

Keywords. Health information system, health information technology, framework, model, evaluation

\section{Introduction}

Global digitization is advancing at a rapid pace and health information systems (HIS) and health information technologies (HIT) are gaining market prominence. The criticality of readily available, safe and usable technologies in healthcare is becoming increasingly vital. The diversity of the HIS and HIT available in the marketplace, is also reflected in the heterogeneity of evaluation models and frameworks currently used in health informatics. Standardization and cross-cultural instrument validation [2] in the creation of relevant models and frameworks is paramount. Such an approach would ensure that safe, reliable and efficient technological solutions are purchased and implemented appropriately in healthcare settings. The objective of this paper is two-fold: 1) to classify models and frameworks published between the years 2010-2020 according to their level of evaluative focus, 2) to identify the countries where these models and

${ }^{1}$ Corresponding author, Amanda L. Joseph, University of Victoria, British Columbia, Canada; E-mail: Amandalynnjoseph@uvic.ca. 
frameworks have been employed for the purpose of evaluation of HIS and HIT, using the International Medical Informatics Association (IMIA) Represented Regions [3].

\section{Methods}

A scoping review following the Arksey and O'Malley methodology [1] was conducted in the EBSCOhost CINAHL $\AA$, Web of Science ${ }^{\circledR}$, IEEE Xplore ${ }^{\circledR}$ and PubMed $\AA$ databases. The keywords utilized were "evaluation AND (framework OR model OR theory)" AND "health information system." Prior to screening the articles, the researchers defined the terms model and framework. This was done to support consistent screening of the articles. Models identified key concepts and their relationships (in the context of systems) and were conceptualized as "the experiences, reflections and insights of scholars and practitioners" [4]. Frameworks were defined as "organizing structures that may be developed into models or theories over time" [4]. Following this, two researchers applied the inclusion and exclusion criteria (Table 1), screened the titles and abstracts of each article using Covidence ${ }^{\circledR}$. A third researcher resolved the differences of opinions in article selection and then a full text review of all remaining articles was completed. Lastly, a market level analysis was conducted and the data extracted (Table 3 ) from the articles was categorized according to: country of use, IMIA represented region [3], level of evaluative focus (Table 2).

Table 1. Inclusion and exclusion criteria

\begin{tabular}{|c|c|}
\hline Inclusion & Exclusion \\
\hline English articles & Language other than English \\
\hline Published between 2010-2020 & Published outside of date parameters \\
\hline Article abstract present & Article abstract absent \\
\hline $\begin{array}{l}\text { HIS or HIT as an intervention with an evaluative } \\
\text { component that: }\end{array}$ & $\begin{array}{l}\text { Editorials and literature reviews that lacked an } \\
\text { evaluative component that focused on: }\end{array}$ \\
\hline a) Used a model or framework to evaluate a technology & a) Clinical or organizational outcomes \\
\hline $\begin{array}{l}\text { b) Developed a model or framework to evaluate a } \\
\text { technology }\end{array}$ & $\begin{array}{l}\text { b) Patient risk factors and health conditions } \\
\text { c) Surgery }\end{array}$ \\
\hline c) Tested a model or framework to evaluate a & d) Medical devices \\
\hline technology & e) Databases or data extracted from a database \\
\hline
\end{tabular}

Table 2. Definitions for micro, meso, macro and multi-levels of evaluative focus [5-8]

\begin{tabular}{lllll}
\hline $\begin{array}{l}\text { Level of } \\
\text { evaluation }\end{array}$ & Micro & Meso & Macro & Multi \\
\hline Definition & $\begin{array}{l}\text { Evaluation of } \\
\text { individual users }\end{array}$ & $\begin{array}{l}\text { Users interacting as } \\
\text { a team, group or }\end{array}$ & $\begin{array}{l}\text { Health system or } \\
\text { inter- }\end{array}$ & $\begin{array}{l}\text { Users interacting with } \\
\text { and using technologies }\end{array}$ \\
& technologies. & $\begin{array}{l}\text { organization using } \\
\text { technologies within } \\
\text { an organization. }\end{array}$ & $\begin{array}{l}\text { organizational } \\
\text { level interactions } \\
\text { using } \\
\text { technologies. }\end{array}$ & $\begin{array}{l}\text { macro merspectives. } \\
\text { macro, meso and }\end{array}$ \\
& & & & \\
\hline
\end{tabular}

\section{Results}

The initial search yielded 363 articles, 78 duplicates were removed, resulting in 285 articles screened for inclusion. From there 215 articles were excluded as they did not meet the inclusion criteria (Table 1), 70 articles were read in full for inclusion and 17 
were excluded as they did not satisfy the inclusion criteria. The remaining 53 articles were then reassessed for inclusion and during the data extraction, phase 11 articles were excluded. These articles were excluded as they represented editorials or literature reviews that summarized the state of the literature but did not propose recommendations to address models or frameworks in HIS and HIT. The screening process of the scoping review was iterative and resulted in a final inclusion of 42 articles. As this was a review of existing publicly available literature, an ethics consult was not required. Some limitations of the study include that findings were guided by the search terms and were limited to articles in the English language only, therefore other relevant articles may have been omitted from the review based on this criteria.

Table 3. Categorical findings of market level analysis

\begin{tabular}{|c|c|c|c|}
\hline Level & Classification & Country of Origin & IMIA Regions [3] \\
\hline \multirow[t]{2}{*}{$\begin{array}{l}\text { Micro- } \\
\text { level }\end{array}$} & $\begin{array}{l}2 \text { Frameworks } \\
{[10,11]}\end{array}$ & \multirow[t]{2}{*}{ Indonesia [10], Netherlands [10] } & \multirow[t]{2}{*}{$\begin{array}{l}\text { Asia Pacific [9], European } \\
{[10]}\end{array}$} \\
\hline & 0 Models & & \\
\hline \multirow[t]{4}{*}{$\begin{array}{l}\text { Meso- } \\
\text { level }\end{array}$} & $\begin{array}{l}9 \text { Frameworks [12- } \\
18,22,23]\end{array}$ & \multirow{4}{*}{$\begin{array}{l}\text { France }[11,15], \text { Germany }[12,17], \\
\text { Austria [12], Canada [13], Indonesia } \\
{[14], \text { Botswana [16], South Africa }} \\
\text { [18], Argentina [19], Australia [20], } \\
\text { Finland [21], India [22], Cyprus [23] }\end{array}$} & \multirow{4}{*}{$\begin{array}{l}\text { European }[11,12,15,17,21, \\
23], \text { North America }[13], \\
\text { Asia Pacific }[14,20,22] \\
\text { African Region }[16,18] \\
\text { Latin America and the } \\
\text { Caribbean [19] }\end{array}$} \\
\hline & 4 Models [11,19-21] & & \\
\hline & & & \\
\hline & & & \\
\hline \multirow[t]{5}{*}{$\begin{array}{l}\text { Macro- } \\
\text { level }\end{array}$} & $\begin{array}{l}18 \text { Frameworks [24- } \\
27,29-31,33-37,39- \\
44]\end{array}$ & \multirow{5}{*}{$\begin{array}{l}\text { Pakistan [24], Brazil [25], Ireland } \\
\text { [26], Tanzania [27], United Kingdom } \\
{[28,40] \text {, Sub-Saharan Africa [29], }} \\
\text { Somalia [30], Australia [31], India } \\
\text { [31], Portugal [32], United States of } \\
\text { America [33], France [33,45], Canada } \\
{[33,44] \text {, Cyprus [34], Iran [35,36], }} \\
\text { Columbia [37], Libya [39], Sweden } \\
\text { [40] }\end{array}$} & \multirow{5}{*}{$\begin{array}{l}\text { Asia Pacific [24], Latin } \\
\text { America and the Caribbean } \\
{[25,37], \text { European }} \\
{[26,28,32-34,40], \text { African }} \\
\text { Region }[27,29,30,39], \text { Asia } \\
\text { Pacific [31], North America } \\
\text { [33,44], Middle East and } \\
\text { North Africa }[31,35,36]\end{array}$} \\
\hline & 4 Models & & \\
\hline & & & \\
\hline & & & \\
\hline & & & \\
\hline \multirow[t]{2}{*}{$\begin{array}{l}\text { Multi- } \\
\text { level }\end{array}$} & $\begin{array}{l}6 \text { Frameworks [45- } \\
50]\end{array}$ & \multirow[t]{2}{*}{ France [45], Canada [50] } & \multirow[t]{2}{*}{$\begin{array}{l}\text { European [45], North } \\
\text { America [50] }\end{array}$} \\
\hline & 0 Models & & \\
\hline
\end{tabular}

The results of the market level analysis (Table 3) indicated that: $50 \%$ of the studies applied a macro-level analysis, $31 \%$ utilized a meso-level perspective, $14 \%$ used a multilevel approach and 5\% assessed HIS and HIT from a micro-level lens. The two articles $[10,11]$ that contextualized HIS and HIT evaluation from a micro-level analysis came from the Asia Pacific and European IMIA represented regions [3], whereas meso and macro-level evaluations were dispersed across many diverse IMIA regions [3]. Of the multi-leveled articles, only two articles [45,50] utilized IMIA regions [3] in their analysis. The remaining four articles represented literature reviews that assessed HIS and HIT but did not specify a country or IMIA represented region [3].

With a collective total of 35 frameworks and eight models, the prominent theme and approach to evaluative design was the framework. However, as evidenced by O'Leary and colleagues [26], a holistic approach utilizing a model and a framework may be a more efficient and effective method. The findings revealed the need for comparability, when assessing HIS and HIT from various perspectives to ensure safety, usability and institutional applicability. However, this field is complex and evaluators must be cognizant of issues that exist in comparing differing nations and jurisdictions. Cultural, 
social factors (e.g. language, time period, health literacy) and geographic customs [2] may alter the interpretation of the research questions and the overall success of the evaluation. Moreover, ignoring these diverse factors could impede the integrity and generalizability of frameworks or models, as each consideration may have direct influence on the outputs and approach to data collection.

\section{Conclusion}

In this scoping review, we have seen a range of models and frameworks that evaluated technology in healthcare settings. As evidenced by the heterogeneity of evaluative design and approaches currently used in health informatics, there is a need for more adaptive methods to HIS and HIT evaluation. To satisfy this critical gap in HIS and HIT assessment, future models and frameworks could be designed to incorporate patient, physician and caregiver journey mapping activities [51]. Additionally, a focus on clinical workflow, human factors (e.g. human information processing capabilities and limitations) and usability engineering could improve the safety and adoption of interactive clinical systems. An appropriate set of criteria (e.g. framework or model) could not only guide HIT implementations but could be leveraged to evaluate clinical systems at various stages of their system development life cycle (SDLC) [52]. As healthcare organizations are highly complex environments, integrating iterative usability testing into HIS and HIT assessment tools may be prudent. Furthermore, designing evaluative schemas from a socio-technical, cognitive [5] and organizational cultural approach may result in more effective HIS and HIT evaluation. Although, dynamic framework and model creation from a holistic and multifactorial lens could be challenging, such an approach may be the only feasible solution to adequately assess the fluid influx of technological innovation in healthcare. A dynamic evaluative approach could ensure that safe and usable technologies are procured and implemented into healthcare settings. Human centric, standardized and generalizable evaluative tools hold tremendous promise for improving healthcare service delivery, patient safety and the global health system.

\section{References}

[1] Arksey H, O'Malley L. Scoping studies: towards a methodological framework. Int J Soc Res Methodol. 2005;8(1):19-32.

[2] Gjersing L, Caplehorn JRM, Clausen T. Cross-cultural adaptation of research instruments: language, setting, time and statistical considerations. BMC Med Res Methodol. 2010;10(1):13.

[3] IMIA Represented Regions [Internet]. IMIA. [cited 2021 Oct 1]. Available from: https://imiamedinfo.org/wp/regional-members/\&gt.

[4] Borycki EM, Kushniruk AW, Bellwood P, Brender J. Technology-induced errors. The current use of frameworks and models from the biomedical and life sciences literatures. Methods Inf Med. 2012;51(2):95-103.

[5] Borycki EM, Kushniruk AW. Towards an integrative cognitive-socio-technical approach in health informatics: analyzing technology-induced error involving health information systems to improve patient safety. Open Med Inform J. 2010;4(1):181-7.

[6] Burns LR, Bradley EH, Weiner BJ. Shortell \& Kaluzny's health care management: Organization, design, and behavior. Sixth ed. Clifton Park, NY: Delmar Cengage Learning; 2012.

[7] Carretero S, Stewart J, Centeno C. Information and communication technologies for informal carers and paid assistants: benefits from micro-, meso-, and macro-levels. Eur J Ageing. 2015;12(2):163-73. 
[8] Macro-Level, Meso-level, and Micro-level Analysis- Course Hero [Internet]. Sociological Perspective. [cited 2021Aug28]. Available from: https://www.coursehero.com/sg/introduction-to-sociology/macrolevel-meso-level-and-micro-level-analysis/.

[9] Erlirianto LM, Ali AHN, Herdiyanti A. The Implementation of the Human, Organization, and Technology-Fit (HOT-Fit) Framework to Evaluate the Electronic Medical Record (EMR) System in a Hospital. Procedia Comput Sci. 2015;72:580-7.

[10] Peute LWP, de Keizer NF, van der Zwan, E. P. A, Jaspers MWM. Reducing clinicians' cognitive workload by system redesign; a pre-post think aloud usability study. Stud Health Technol Inform. 2011;169:925-9.

[11] Hadji B, Martin G, Dupuis I, Campoy E, Degoulet P. 14 Years longitudinal evaluation of clinical information systems acceptance: The HEGP case. Int J Med Inf. 2016 Feb;86:20-9.

[12] Honekamp W, Ostermann H. Evaluation of a prototype health information system using the FITT framework. J Innov Health Inform. 2011 Mar 1;19(1):47.

[13] Heidebrecht CL, Kwong JC, Finkelstein M, Quan SD, Pereira JA, Quach S, Deeks SL. Electronic immunization data collection systems: application of an evaluation framework. BMC Med Inform Decis Mak. 2014;14(1):5.

[14] Faridah L, Rinawan FR, Fauziah N, Mayasari W, Dwiartama A, Watanabe K. Evaluation of Health Information System (HIS) in The Surveillance of Dengue in Indonesia: Lessons from Case in Bandung, West Java. Int J Environ Res Public Health. 2020 Mar 10;17(5):1795.

[15] Rejeb O, Pilet C, Hamana S, Xie X, Durand T, Aloui S, et al. Performance and cost evaluation of health information systems using micro-costing and discrete-event simulation. Health Care Manag Sci. 2018 Jun;21(2):204-23.

[16] Seitio-Kgokgwe O, Gauld RDC, Hill PC, Barnett P. Development of the National Health Information Systems in Botswana: Pitfalls, prospects and lessons. Online J Public Health Inform. 2015;7(2):e210.

[17] Sunyaev, A, Pflug, J. Research Toward the Practical Application of a Risk Evaluation Framework: Security Analysis of the Clinical Area within the German Electronic Health Information System (2011). Proceedings of International Bled eConference (Bled 2011), Bled, Slovenia, June 12-15, 2011, pp. 156 168.

[18] Hanmer LA, Isaacs S, Roode JD. Factors associated with health information system success: results of a survey of hospitals in South Africa. Stud Health Technol Inform. 2010;160(Pt 1):347-51.

[19] Borbolla D, Otero C, Lobach DF, Kawamoto K, Gomez Saldaño AM, Staccia G, Lopez G, Figar S, Luna D, Bernaldo de Quiros FG. Implementation of a clinical decision support system using a service model: results of a feasibility study. Stud Health Technol Inform. 2010;160(Pt 2):816-20.

[20] Yu P. A multi-method approach to evaluate health information systems. Stud Health Technol Inform. 2010;160(Pt 2):1231-5.

[21] Vahteristo A, Jylhä V. Effects of User Participation in the Development of Health Information Systems on Their Evaluation Within Occupational Health Services. Stud Health Technol Inform. 2020 Nov 23;275:207-211.

[22] Gudi N, Godinho MA, Saha D, Narasimhan P. Sociotechnical evaluation of a health management information system in South India. BMJ Innov. 2020 Oct;6(4):164-9.

[23] Stylianides A, Mantas J, Pouloukas S, Roupa Z, Yamasaki E. Evaluation of the Integrated Health Information System (IHIS) in Public Hospitals in Cyprus Utilizing the DIPSA Framework. Acta Inform Medica. 2019;27(4):240.

[24] Nawaz R, Khan SA, Khattak T, Nasir F, Abbas K. Interventional Study for Improving Health Information System in Khyber Pakhtunkhwa, Pakistan. Curēus. 2020;12(11):e11785.

[25] Mussi CC, do Valle Pereira CD, de Oliveira Lacerda RT, dos Santos EM. Pre-Implementation evaluation of a nationwide information system for university hospitals: lessons learned from a study in Brazil. Behav Inf Technol. 2018 Mar 4;37(3):217-31.

[26] O'leary P, Carroll N, Clarke P, Richardson I. Untangling the Complexity of Connected Health Evaluations. IEEE; 2015.

[27] Kiwanuka A, Kimaro H, Senyoni W, Thobias J. A framework for the acceptance process of District Health Information System for vertical health programmes. IIMC International Information Management Corporation Ltd; 2015.

[28] Cresswell KM, Worth A, Sheikh A. Actor-Network Theory and its role in understanding the implementation of information technology developments in healthcare. BMC Med Inform Decis Mak. 2010;10(1):67.

[29] Herman H, Grobbelaar SS, Pistorius C. The design and development of technology platforms in a developing country healthcare context from an ecosystem perspective. BMC Med Inform Decis Mak. 2020;20(1):55.

[30] Askar A, Ardakani M, Majdzade R. Bridging gaps in health information systems: a case study from Somaliland, Somalia. East Mediterr Health J. 2017;23(11):764-73. 
[31] Tiwari VK, Kumar K, T.P. SR, Kulkarni PD. Standards, Frameworks and Practices in Health Management Information and Evaluation Systems (HMIES) in Australia and India: Lessons for Future Transition in India? J Health Manag. 2016 Mar;18(1):70-83.

[32] Grenha Teixeira J, Pinho NFd, Patrício L. Bringing service design to the development of health information systems: The case of the Portuguese national electronic health record. Int J Med Inform. 2019;132:103942.

[33] Kushniruk A, Beuscart-Zéphir M, Grzes A, Borycki E, Watbled L, Kannry J. Increasing the Safety of Healthcare Information Systems through Improved Procurement: Toward a Framework for Selection of Safe Healthcare Systems. Healthc Q. 2010;13(SP2):53-8.

[34] Stylianides A, Mantas J, Roupa Z, Yamasaki EN. Evaluation of an Integrated Health Information System (HIS) in a Public Hospital in Cyprus: A Pilot Study. Stud Health Technol Inform. 2017;238:44-7.

[35] Farzandipour M, Meidani Z, Nabovati E, Sadeqi Jabali M, Dehghan Banadaki R. Technical requirements framework of hospital information systems: design and evaluation. BMC Med Inform Decis Mak. 2020;20(1):61.

[36] Abdi Z, Majdzadeh R, Ahmadnezhad E. Developing a framework for the monitoring and evaluation of the Health Transformation Plan in the Islamic Republic of Iran: lessons learned. East Mediterr Health J. 2019;25(6):394-405.

[37] López DM, Blobel B, Gonzalez C. Quality evaluation of health information system's architectures developed using the HIS-DF methodology. Stud Health Technol Inform. 2010;156:21-31.

[38] Logan J. Electronic health information system implementation models - a review. Stud Health Technol Inform. 2012;178:117-23.

[39] El Oakley RM, Ghrew MH, Aboutwerat AA, Alageli NA, Neami KA, Kerwat RM, Elfituri AA, Ziglam HM, Saifenasser AM, Bahron AM, Aburawi EH, Sagar SA, Tajoury AE, Benamer HT; National Health Systems Conference. Consultation on the Libyan health systems: towards patient-centred services. Libyan J Med. 2013;8(1):20233-9.

[40] Prodinger B, Taylor P. Improving quality of care through patient-reported outcome measures (PROMs): expert interviews using the NHS PROMs Programme and the Swedish quality registers for knee and hip arthroplasty as examples. BMC Health Serv Res. 2018;18(1):87.

[41] Reynolds HW, Sutherland EG. A systematic approach to the planning, implementation, monitoring, and evaluation of integrated health services. BMC Health Serv Res. 2013;13(1):168.

[42] Gajanayake R, Sahama T, Lane B. The role of human factors when evaluating information accountability for eHealth systems. Stud Health Technol Inform. 2013;194:97-102.

[43] Kushniruk A, Borycki E, Kuo M, Kuwata S. Integrating technology-centric and user-centric system testing methods: ensuring healthcare system usability and safety. Stud Health Technol Inform. 2010;157:181-6.

[44] Bassi J, Lau F, Hagens S, Leaver C, Price M. Knowledge translation in eHealth: building a virtual community. Stud Health Technol Inform. 2013;183:257-62.

[45] Augusto V, Rejeb O, Xie X, Aloui S, Perrier L, Biron P, Durand, T. Performance evaluation of Health Information Systems using ARIS modeling and discrete-event simulation. IEEE; 2015.

[46] Delnord M, Tille F, Abboud LA, Ivankovic D, van Oyen H. How can we monitor the impact of national health information systems? Results from a scoping review. Eur J Public Health. 2020;30(4):648-59.

[47] Yusof MM. A Socio-Technical and Lean Approach Towards a Framework for Health Information Systems-Induced Error. Stud Health Technol Inform. 2019;257:508-512.

[48] van Mens HJT, Duijm RD, Nienhuis R, de Keizer NF, Cornet R. Determinants and outcomes of patient access to medical records: Systematic review of systematic reviews. Int J Med Inform. 2019;129:226-33.

[49] van Mens, Hugo J T, Duijm RD, Nienhuis R, de Keizer NF, Cornet R. Towards an Adoption Framework for Patient Access to Electronic Health Records: Systematic Literature Mapping Study. JMIR Med Inform. 2020;8(3):e15150.

[50] Lau F, Price M, Keshavjee K. From Benefits Evaluation to Clinical Adoption: Making Sense of Health Information System Success in Canada. Healthc Q.2011;14(1):39-45.

[51] Joseph AL, Kushniruk AW, Borycki EM. Patient journey mapping: Current practices, challenges and future opportunities in healthcare. Knowledge management \& e-learning. 2020;12(4):387-404.

[52] Kushniruk A. Evaluation in the design of health information systems: application of approaches emerging from usability engineering. Comput Biol Med. 2002;32(3):141-9. 